\title{
conelchilenoresistentearte, Solidaridad: Chile Vive, una Exposición en España contra el Chile Dictatorial
}

\author{
withthechileanresistantart, Solidarity: Chile Vive, an \\ Exposition in Spain against the Dictatorial Chile
}

\author{
Francisco Godoy \\ Universidad Autónoma de Madrid \\ fagodoy@puc.cl
}

Resumen • En 1987 se realiza en Madrid Chile Vive, megaexposición que incluye diferentes manifestaciones artísticas para dar cuenta de la vitalidad cultural de Chile en dictadura. El ensayo, partiendo de una discusión conceptual sobre el problema de la exposición de arte latinoamericano en el extranjero, analiza la configuración de esta exposición, centrándose en las artes visuales como alineación unitaria de un discurso político de país, además de examinar su repercusión en la prensa española de la época. Por otro lado, reflexiona sobre las inclusiones y exclusiones de artistas y las proyecciones de Chile Vive en el problema de la exposición del arte chileno en el extranjero, particularmente el de un periodo tan complejo como el producido durante la dictadura militar.

Palabras clave: Arte chileno, exposición en el extranjero, arte y política, dictadura.

Abstract - In 1987, Chile Vive, a mega-exhibition that included different artistic expressions, was performed in Madrid to inform people about the cultural vitality of Chile during their dictatorship. This essay will focus on a conceptual discussion about the problem of Latin American art exhibitions abroad. It will analyze the configuration of the mentioned exhibition, focusing on visual arts as a unitary alignment of a political discourse of nation. The text will also examine the repercussion in the Media of Spain in that period of time. On the other hand, the article will develop some thoughts on the artists incorporations, exclusions and projections of Chile Vive, focusing on why the exhibition of Chilean art abroad might be problematic, particularly the ones that belongs to this complex period of time; the military dictatorship.

Keywords: Chilean art, art exhibits abroad, art and politic, dictatorship. 


\section{CARTOGRAFÍAS, TERRITORIOS}

Hablar de cartografía en artes visuales implica hablar de «lugares y no-lugares» (Derrida, 1997), de geopolíticas que llaman a construir un mapa (conceptual-contextual) que necesariamente se presente como digresión en relación al territorio del que habla. En este sentido planteo una geopolítica de la imagen del Chile presente en la exposición Chile Vive realizada en Madrid en 1987, de cómo ciertas dinámicas de poder se posan en una particular arquitectura (museográfica y política).

Para realizar este mapeo resulta necesario delinear ciertas premisas que permitan comprender desde dónde se dibuja una cartografía así. El trabajo con imágenes aquí no se presenta como trabajo con documentos de la historia (error positivista), sino que con objetos-imágenes situados en un tiempo dialéctico (no trivial) de anacronismo (DidiHuberman): las imágenes tienen una cierta historia narrable, pero a la vez son historias a partir del movimiento de poderes específicos que sintomatizan la historia (en un objetoimagen histórico se encuentran, colisionan y/o funden plásticamente muchos tiempos posibles). En concordancia con Sergio Rojas «pienso aquí en imagen como el cuerpo visual de una suerte de resistencia a la historia, en cierto modo la imagen deviene una fantasía irreductible a sentido» (286). No sería así la imagen ni intemporal ni presentaría una historicidad estática. Su temporalidad es reconstruida por su elemento histórico dialectizado por el anacronismo que atraviesa. Una dialéctica sin la idea de la imagen como síntesis sino como eterno retorno. Una dialéctica visual borrada, como desarrollaré a lo largo de este trabajo, en el montaje que una operación expositiva como ésta desplegó.

El tiempo anacrónico en la imagen se articula además en tensiones con el espacio físico y los códigos culturales, lo que plantea nuevas posibilidades de repensar las formas de apropiación de obras y también, los tipos de relaciones de poder espacial que se establecen, entre visibilidad e invisibilidad, entre significaciones e interpretaciones en disputa situadas específicamente en «historias locales». Resulta necesario poner en sospecha entonces aquel discurso generalizado de una sociedad fuertemente marcada por la desterritorialización, en la que el universalismo borra los matices de la producción local y el posicionamiento en un cierto espacio urbano y museográfico/galerístico, discursivo y político. Entender una exposición de arte como ésta requiere una necesaria comprensión de las posibilidades de territorialización de ella en cuanto ubicada en un particular tejido urbano o contexto, «localidad de producción, sitio enunciativo, coyuntura de debate, particularidad histórico-social de una trama de intereses artísticos y de luchas culturales que especifican el valor situacional y posicional de cada dinámica de arte» (Richard, 117), concretizado en un particular espacio expositivo (histórico) y con la presentación de ciertos artistas.

Una exposición aparece así como un espacio de enunciación entre lo pragmático y lo teórico, un discurso elaborado tanto en obras como en textos. Esta tensión se agudiza en las exposiciones extranjeras, donde se puede poner en evidencia la tentación de una actitud documental de objetos estéticos en la lógica Norte-Sur, cuya conceptualización de un arte del sur (arte de la periferia, de los márgenes, tercermundista) corre riesgos de exotizar las estrategias plásticas y discursivas de un cierto entramado de desarrollo artístico e intelectual bajo la mirada metropolitana. Una operación inversa ocurre de forma normalizada en las exposiciones extranjeras en países del sur, a través de una perpetua- 
ción del discurso de aquel arte central (europeo, estadounidense) como lo universal en el arte, como el tiempo al cual se debe llegar.

Siguiendo a Derrida, se podría pensar la diferencia entre unos y otros tipos de operaciones expositivas no solo como un concepto/categoría, sino que como proceso, como espacio de articulación conceptual (cartografía) que re-plantea el problema de la historia (y del contexto) como construcción de «diferencias» (Derrida, La diferencia, 11). La diferencia aparece entonces siempre en una correspondencia presente y actualizable, donde los elementos se conjugan para establecer relaciones que se enlazan con el pasado y sus marcas, construyendo además (afirmando o desmitificando) huellas de futuro. Deviene la diferencia en su articulación con los tiempos y los espacios en discordia, en confrontación activa fuera de toda estaticidad.

En relación a este problema en las artes visuales se podría pensar, como lo hace Nelly Richard, que «el centro se auto-asigna el privilegio de la identidad (la universalidad del arte) mientras le reserva a la periferia el uso estereotipado de la (diferencia como simple ilustración de contexto, destinada a erotizar o folclorizar la imagen del Otro» («El régimen crítico estético», 118). A este respecto resulta interesante también el planteamiento de David Pérez en la medida que complejiza el anterior: «debemos actuar con una extremada cautela a la hora de aproximarnos a esta eclosión identitaria que, en muchos casos, actúa más que como una toma de palabra por parte de aquellas voces que tradicionalmente han carecido de eco, como una mera estrategia comercial que desde los propios centros de poder $-\mathrm{y}$, de una manera especial, si éstos están vinculados al ámbito artístico- es utilizada como un simple argumento de especulación» (22).

En este sentido, en cuanto el pensamiento de la diferencia interroga la presencialidad, en las posibilidades múltiples de ciertos artistas/curadores de reposicionarse de forma irregular fuera de esta lógica centro/periferia, esta idea estaría en un constante estado de examen - en perpetua cautela—, eso sí, teniendo en cuenta la permanencia de estas apropiaciones discursivas por ciertos espacios de poder respecto, en este caso, a categorías de lo latinoamericano (lo híbrido, lo barroco, lo mestizo) o problemas de lo latinoamericano (lo indígena, la pobreza, las dictaduras) como lugares comunes de acumulación de lo diverso en términos meramente referenciales en cuanto a contenido sin una problematización respecto a sus formas.

En este sentido habría que pensar obras y exposiciones como actos de enunciación constante de la diferencia (la identidad) y la representación en unas particulares relaciones geopolíticas tanto en la selección de obras como en el montaje. Particularmente para el arte latinoamericano - en una tensión permanente entre integración a la «modernidad europea» y las «culturas de origen», marcado por una cierta «cultura de la resignificación» (Richard, La estratificación de los márgenes, 55) de la norma dominante («lo universal») - el problema se agudiza con los tránsitos al extranjero. En el nuevo contexto, el espacio se articula como sitio enunciativo sobre lo propio y lo otro, siempre amenazado por las tentaciones de la antropología del exotismo ${ }^{1}$, donde las señales indicativas de una

El curador cubano Gerardo Mosquera propone: «el término sautenticidad ha sido empleado, desde un relato de pureza de los orígenes, para descalificar la cultura postcolonial acusándola de derivativa de Occidente. Este uso resulta aún más problemático en una época cuando ocurren complejas readecuaciones de las identidades: identidades múltiples, identidades en forma de cajas chinas o matiushkas, neoidentidades, mezcla de identidades, desplazamiento entre ellas, juegos étnicos> [...] con demasiada frecuencia se ha valorado el arte que manifiesta en explícito la diferencia, o mejor satisface las expectativas de ‘otredad del neoexotismo posmoderno» (Mosquera). 
identidad tienen una vida extremadamente corta luego de la cual mueren en el estereotipo y la funcionalidad política.

\section{CHILE VIVE}

En el contexto de estos debates que en América Latina tienen un punto álgido en los años 80, España (con Felipe González a la cabeza) organiza Chile Vive ${ }^{2}$, exposición que se realiza con un claro propósito de promover el fin de la dictadura de Pinochet, pero sin dar cuenta ni responder a estos problemas y debates presentes en la inestable estructura intelectual chilena de la época.

La muestra, con un coste total de 55 millones de pesetas (330.000 euros aproximadamente), se realiza en la totalidad del edificio del Círculo de Bellas Artes de Madrid (fig. 1), curada por Rafael Blázquez Godoy y articulada a partir de dos conceptos: arte y cultura. Con estas categorías la exposición incluyó fotografía, arquitectura, pintura, escultura, literatura, medios de comunicación, derechos humanos, video, teatro y música, que se manifiestan, como plantea en el catálogo José Joaquín Brunner, en diferentes «espacios de simbolización [...] que introducen en la sociedad y en la cultura la experiencia reprimida por el régimen militar, y que la amplifican bajo las formas del discurso y de la obra, de la prensa y la música, del análisis histórico y la crítica social, de la literatura o la liturgia, del cine documental o la proposición académica» (19).

La exposición fue acompañada de un catálogo unitario (para no romper con la lógica articuladora) de todas las manifestaciones presentes acompañadas de textos críticos. En sus 360 páginas en papel couché, cuya portada cita la configuración tricolor de la bandera chilena con Chile Vive rotulado al revés — queriendo mostrar el «otro lado» del Chile que todos conocían a través de la prensa negra internacional-, intenta pensar la exposición desde algunas relaciones posibles de establecer entre arte y política en España, como retorno del hijo pródigo, del hermano o del amante. Respecto a esta relación desigual Milan Ivelic plantea dos asuntos sumamente recurrentes en la historiografía del arte chileno: la unilateralidad y el aislamiento: «la carencia sistemática de intercambios artísticos debido a la asimetría del circuito de arte — agravado por el aislamiento del país— tornó completamente unilateral el contacto, hecho que se ha traducido y se traduce en el desconocimiento de lo que somos y hacemos» (55).

2 Institucionalmente fue organizada por el Ministerio de Cultura junto a la Comunidad de Madrid, el Instituto de Cooperación Iberoamericana (ICI) y el Círculo de Bellas Artes. Colaboraron con la exposición además la Caja de Madrid, el Ayuntamiento de Barcelona, la Fundación Banco Exterior de España e Iberia. La contraparte chilena estuvo a cargo de CENECA (Centro de Indagación y Expresión Cultural y Artística), institución/editorial que nace tras el golpe de Estado y que realiza investigaciones principalmente centradas en el teatro como proceso creador en el contexto histórico específico, en colaboración con la Galería Carmen Waugh.

Los medios de comunicación dan cuenta de la itinerancia de la exposición: luego de Madrid, ella pasaría a Barcelona, Francia e Italia. Sin embargo, ni uno de ellos da cuenta de los espacios en que se ubicará ni de fechas exactas. Según testimonia el libro Chile vive: memoria activa, la exposición sufrió un proceso de edición y pasó de forma reducida a Barcelona (no se especifica en qué lugar fue montada), donde terminaría su viaje. Al parecer, este afán de movilidad falló en su ejecución y la exposición fue reemplazada por Cirugía Plástica, que se realizó dos años después en Berlín. 
Claramente la intención de la muestra no era mostrar "vanguardia» — aunque también lo hiciese - sino que dar una mirada holística a la producción que se realizó en Chile entre 1973 y 1987, período en que, como plantea nuevamente Brunner, la vida cotidiana de los chilenos fue marcada (con ciertos matices) por «una cultura del miedo, de una juventud que ha perdido los horizontes de futuro, de un desarraigo de la memoria histórica, de una polarización social que divide a los sectores identificados con el régimen de aquellos que son excluidos por éste o que disienten de los medios que emplea y los fines que persigue» (19).

La exposición de "arte» (y no de cultura, si mantenemos esa división curatorial) se presentó en el Salón de Bailes del Círculo (fig. 2), una bóveda rococó de 15 metros de altura desdibujada a partir del montaje de muros blancos que establecieron el circuito del recorrido en formato de cubos diseñado por Juan Ariño: para Gonzalo Díaz, Ariño limpió, pulió y «transformó un lugar cargado al parecer de oscuras historias y negocios del franquismo, en un espacio sintético, denotador, ordenador y emisor» (35). El cuadro de Roberto Matta dio la bienvenida en el Salón, viéndose ya sus 2,5 por 4 metros antes de entrar a través de una amplia mampara de cristal. Matta, quien se integró a las vanguardias surrealistas sin alejarse nunca de la pintura como medio ni de su compromiso con la libertad ${ }^{3}$ y América Latina ${ }^{4}$, realiza de forma exclusiva para la exposición un cuadro titulado Munda y Desnuda: la libertad contra la opresión (fig. 3), que fue caballo de Troya de Chile Vive (nombrado incluso como el Guernica chileno), y pasó luego a formar parte de la colección del Museo Español de Arte Contemporáneo (actual Museo Nacional Centro de Arte Reina Sofía) por un coste de 8 millones de pesetas (50.000 euros). En los costados de este cuadro se colgaron cuatro pinturas de Carlos Maturana (Bororo), uno de los principales representantes del neoexpresionismo primitivista nacional. La sala detrás de Matta expuso el informalismo abstracto de José Balmes y su mujer Gracia Barrios, junto a las esculturas a ras de suelo de bañistas en hierro forjado negro de Juan Egenau (fig. 4). A la derecha se encuentran dos salas individuales: la primera para la instalación objetual de Francisco Brugnoli Fractal A2R2, que utiliza objetos "populares» (azulejos blancos, bombillas, cables eléctricos y polietileno) encontrados, instalados y redistribuidos en la sala; la segunda presenta la instalación de Gonzalo Mazza Al este del sol, al oeste de Suramérica (Hiroshima-Isla de Pascua), un trabajo que tensa la gráfica computarizada de guerra (en un televisor) con la fotocopia gigantografiada en plástico de las indescifradas tabletas de Rapa Nui (otra gráfica).

Hacia el otro lado de la «sala informalista» se encuentran los dibujos y pinturas de repetición de Roser Bru, quien junto a la pareja informalista, Alberto Pérez y Eduardo Martínez Bonatti formaron en los años 60 el Grupo Signo. En la misma sala se exponen

En el catálogo de la exposición, en un breve texto que no plantea los aportes de Matta a la plástica internacional, sino que se centra en su compromiso político, se plantea: «Matta ha demostrado reiteradamente su compromiso con la libertad, tanto en la creativa como en la política. Prueba de ello es que en 1963 pinta Grimau, la hora de la verdad; en 1968, en Cuba, Para que la libertad no se convierta en estatua, y más tarde, realiza obras para el Movimiento de Liberación de Angola. En 1973 se organiza la exposición «Per il Cile com Matta» y otras muestras de apoyo a Chile en 1975 y 1978» (Chile Vive, 292).

4 Matta, a propósito de la proximidad del V Centenario del Descubrimiento de América (tema de su particular interés), plantea una idea sumamente atingente respecto al tipo de relación que España establece (o debería establecer) con América: "A mi juicio, en el 92 habría que hacer un verdadero descubrimiento de América [...] creo que esta aparición debe ser como el encuentro de un esposo con una esposa, es decir no muy paternal ni sometido: tiene que ser un encuentro matrimonial, un encuentro únicamente semejante al de la procreación» (cit. en García-Garzón, 1987). 
las pinturas «metafísicas» y formalistas de Rodolfo Opazo y las sintéticas y reiterativas de Nemesio Antúnez, más otras esculturas negras de Egenau. La sala contigua vuelve a presentar esculturas de Egenau, esta vez de cuerpos con armaduras (fig. 5), junto a cuatro retratos del «realismo objetivo» de personajes-tipo de Ricardo Yrarrázaval y la pintura aeropostal Todas las de la ley de Eugenio Dittborn. Luego se montó un espacio individual para la instalación self-portrait de Carlos Leppe (fig. 6), que entrecruza elementos como un cerro de pelos coronado por una virgen, una bandera chilena a medio bordar, desechos, maderas y una televisión encendida con el registro de una acción de arte suya (Leppe realizó además una acción de arte en la Teatroneta del Círculo).

La siguiente sala presentó la pintura libre de Samy Benmayor (neoexpresionismo), para concluir con la sala dedicada al conceptualismo crítico y paródico de Gonzalo Díaz $^{5}$, quien presenta las obras Para escribir en el cielo (1986) y Pintura por encargo (1985), acompañadas de esculturas en bronce de pequeño formato de Mario Irarrázabal. Este último además colocó una mano gigante en la acera de la calle Alcalá (la segunda de una serie de tres: Punta del Este y Desierto de Atacama), realizando una operación de salida del espacio museístico como gesto de saludo al público español (fig. 7), lo que para Antúnez y otros será «la obra-lema de la exposición» (Antúnez, 33). Esta escultura fue adquirida por el gobierno español por 2.500 dólares (1.900 euros) y hoy se encuentra en el Parque Rey Juan Carlos I de Madrid.

Heterogéneas son las tendencias artísticas presentadas (en solo una sala del Círculo), las cuales quieren presentar una cierta coherencia lineal pero terminan cruzando estrategias plásticas disímiles que no encuentran diálogo posible, como los montajes Yrarrázaval-Dittborn, Díaz-Irarrázabal o la contigüidad Leppe-Benmayor. Así también se presentan los textos críticos de quienes escribieron para el catálogo, donde se suceden uno, dos o tres intelectuales enfocados a cada ámbito específico (literatura, fotografía, vídeo, etc.); particularmente sobre artes visuales escribe Nelly Richard, teórica postestructuralista que ha centrado su trabajo crítico en la «Escena de Avanzada», Alberto Pérez, «hispanoamericanista» pintor, poeta y profesor de historia del arte de la Universidad de Chile y Milan Ivelic, quien, desde un enfoque «humanista» escribe la historia cronológica y metódica del arte chileno, presentando puntos de vista variados pero que en ningún momento se colocan en diálogo con las otras escrituras (presentes y ausentes) y con las condiciones de producción de textos en aquel momento.

Si bien discursivamente se asume en Chile Vive la imposibilidad totalizadora de la exposición ${ }^{6}$, en términos programáticos, textuales y museográficos el planteamiento es

Díaz, Leppe, Dittborn, Rosenfeld y en alguna medida Brugnoli fueron los «representantes» de la «Escena de Avanzada" en Chile Vive, la cual aglomera a un grupo de artistas, escritores y teóricos, según el criterio de selección de Nelly Richard, que desde la acción de arte o las técnicas de reproducibilidad se preguntaron en torno al significado del arte y las condiciones límites de su práctica en el marco de una sociedad en represión, que ha perdido sus redes y conexiones de identidad, reposicionándose en los residuos de aquel espacio resquebrajado. La creatividad aparece ahí como fuerza que rompe con el orden establecido por las gramáticas del poder, como única alternativa ante la barbarie. A la vez, anulan el privilegio de lo estético, como categoría ideológica dominante, reivindicando un concepto de obra-acontecimiento en (interviniendo) la cotidianidad social de forma des-ilustrativa, oponiéndose a las formas de "arte solidario» o de resistencia convencionalista que se había gestado con estereotipos del lenguaje. Se instaura como un entramado textual y visual que rompe tajantemente con las estrategias tradicionales del arte (la pintura y la escultura) para realizar experimentaciones límites en la re-construcción (del cuerpo, la ciudad, lo social) ante el quiebre de todo espacio comunicativo pre-existente.

El primer texto del catálogo, donde Javier Solana, Ministro de Cultura, da por inaugurada la exposición, parte diciendo: «la pretensión de esta exposición es ciertamente ambiciosa: comunicar el proceso cultural 
distinto: se pretende abarcar a la gran mayoría de las manifestaciones artístico-culturales (exceptuando la danza y poco más) con una estructura tradicionalista de división disciplinar, amparado por algunos de los principales intelectuales chilenos de oposición al régimen militar y bajo el alero de la totalidad de los salones del Círculo de Bellas Artes. Dicho montaje además resulta al menos paradójico: si bien quiso separar las salas del edificio en función de las diferentes disciplinas presentes, esta división resultó forzada, en cuanto Dittborn también presenta video y el videoarte de Lotty Rosenfeld queda en ese otro espacio «video» dialogando con documentales y no con la obra, por ejemplo, de Leppe o Díaz; esto se intensifica en la medida que presentó un discurso claramente unificador, anacrónico, aunando tiempos discontinuos, pero que resultaron fragmentados y fracturadores entre lo que estaba ocurriendo en cada disciplina como inconexo. Se armó una historia de las artes visuales capaz de generar una estructura armónica con las otras manifestaciones culturales (todas ellas fragmentadas, incluso algunas, como la música o el teatro, bastante más reducidas) ${ }^{7}$, queriendo hacer patente una consonancia/resistencia de las artes como respuesta simbólica y sintomática unitaria ante el régimen desarticulador de estrategias relacionales de Pinochet (lo que resulta institucionalmente valorable), pero sin dar demasiado espacio al debate sobre las recuperaciones, ausencias y fisuras de aquel momento clave, uno de los más fecundos, de la teoría y el arte chileno.

\section{EL PAPEL DE LA CRÍTICA}

Ese sentido que el comisariado y la intelectualidad quiso dar a Chile Vive se puede sentir también en la recepción de los medios de comunicación escrita españoles ${ }^{8}$, quienes, acostumbrados en los años 70 y 80 al Chile dictatorial - reporteando un sinnúmero de elementos respecto a los cambios que sufría el régimen de Pinochet en el contexto de las dictaduras del Cono Sur - en cierta medida ven en la exposición un gesto de quiebre diferencial (quizá no tan radical, pero significativo) con relación a lo que los españoles leían sobre el país. Con un fuerte compromiso cívico-político, la exposición es vista por la crítica especializada como un gesto eminentemente solidario de la sociedad española con Chile. Esto se corrobora con la amplia asistencia a la inauguración (fig. 8), lecturas poéticas, recitales musicales y presentaciones teatrales, según cuenta la prensa. Sin lugar a dudas, este asunto de la visión de un país a otro se coloca en el debate público, o más bien, se coloca en el escenario público como recordatorio de la historia española reciente,

de Chile, hoy». Un par de páginas más adelante, en un texto que describe el catálogo en sí (sin autor), se plantea: "Queda siempre, en el fondo de cualquier selección, el tema de su propia arbitrariedad. La Exposición y el Catálogo que la resume pretende ser una muestra indicativa más que representativa del conjunto del fenómeno cultural y artístico. Decenas de circunstancias propias de las condiciones en que vive Chile y en que se prepara la Exposición hacen imposible aspirar a otra cosa» (Chile Vive, 9 y 14).

En mayor o menos medida, algunas de las reflexiones que se presentan aquí podrían ser replicables a lo que sucedió en otros ámbitos del quehacer artístico y cultural chileno presentes en la exposición.

Según he podido indagar en diferentes lugares, aparecieron un total de 84 artículos en la prensa, de distintas dimensiones, desde un reportaje acabado sobre la exposición a pequeñas reseñas sobre algún elemento particular. Del total de los artículos, 41 se referían a la exposición de forma general, 15 estuvieron dedicados a la literatura, 15 al teatro, 9 a la plástica, 2 a la música y 2 al video. De los 25 periódicos que circulaban en aquel momento y que cubrieron la exposición, fueron cuatro los que destacaron en su cobertura: El País (13 artículos), Diario 16 (13 artículos), ABC (13 artículos) y La Guía del Ocio (8 artículos). 
pero también como proyectiva (no menor) de las relaciones que España podría establecer con otros países latinoamericanos, dando cuenta del interés por repetir la experiencia con otras ex-colonias.

La prensa destaca la cantidad de artistas presentes en Chile Vive: casi un centenar, de los cuales cerca de 40 (entre artistas e intelectuales) se trasladaron a Madrid. La visita que realizan Nicanor Parra, Raúl Zurita y Enrique Lihn fue bastante cubierta por la prensa, sin embargo, muy pocos artículos especializados aparecen sobre la obra de los artistas visuales (a excepción de Irarrázabal y Matta), de los cuales solo Matta (residiendo en Europa), Irarrázabal (que debía realizar el montaje escultórico en la calle Alcalá) y Leppe (residiendo en Europa y para realizar su performance) visitaron Madrid; la presencia de los intelectuales y críticos de arte invitados (particularmente Milan Ivelic) no fue cubierta por la prensa.

Se plantea con relación al origen de los artistas que éstos desarrollan su trabajo tanto fuera como dentro del país. Sin embargo, Matta y Leppe son los únicos que viven en el exterior al momento de la exposición sin siquiera estar exiliados, figura retórica repetida en los medios.

Un interesante artículo de prensa -el único crítico con la exposición- es el de Ángel González García (1987), profesor de Historia del Arte de la Universidad Complutense de Madrid, quien, desde la idea de la piedad y la benevolencia política, plantea:

Así debíamos ser nosotros en otro tiempo: testigos involuntarios de la muerte y la ignominia. Bastaba con que pudiéramos declarar que habíamos visto esto o aquello, que lo habíamos oído o lo sabíamos, para que la Bienal de Venecia nos abrumara con su benevolencia y casi nos sepultara en su compasión. Pero ya lo hemos olvidado y ahora somos nosotros quienes nos arrogamos el dudoso privilegio de compadecer a los que sufren y felicitarnos de que no hayamos muerto [...] Advertidos seguramente de la ridiculez de una exposición testimonial — palizas, banderas, consignas, sangre y fuego-, los responsables de Chile vive han caído en el vicio contrario: aquí no pasa nada que no haya pasado antes en otro lugar; el arte, por fortuna, sigue vivo [...] Me gustaría saber lo que Dittborn y Leppe piensan de todo esto. Por el contrario, lo que piensa el autor de la gigantesca mano que surge de la acera de la calle Alcalá no me interesa nada.

Replantea González García el problema de la representatividad visual y las connotaciones particulares/diferenciales de la instalación y la performance en un espacio que claramente esta en el filo del voluntarismo político; sin embargo, el autor no vuelve a publicar otro artículo que profundice en los elementos críticos que menciona ni nadie responde a sus provocadoras palabras que dan pie a un debate que no interesa continuar.

En resumidas cuentas, la masiva pero moderada recepción española a través de los medios se puede entender en una dualidad: por un lado, lo esperado (las esperanzas de cambio político), y por otro, lo editado/sorprendido (una historia del arte desconocida e insospechada - vía lenguaje universal-conceptual del arte- de un país de América Latina). Un montaje/relato/argumento óptimo, como algún artículo plantea, ambicioso, unitario y ético: desgarrador, empático, afectivo, esperanzado y optimista, en definitiva, de supervivencia en la coyuntura del problema chileno, que sirve como recipiente que fragua el discurso de la vida en un régimen de muerte, que recibió una cálida acogida del público madrileño que se enteró de la modernidad de Chile. Es quizá también recibido como una fiesta adelantada (transiciológica) y un ayuda-memoria para la España del momento, de que no todo ocurre en libertad. 


\section{LOS OTROS}

El curador de la exposición, Blázquez Godoy, plantea su proyecto a la crítica como un espacio de neutralidad; explica que esta «reconstrucción de un ámbito cultural, de por sí diversificado, se fundamentó en un proceso de selección que no supo de criterios excluyentes ni en lo estético ni en lo partidista» (Godoy cit. en Oliva, 44), obviando la operación de recorte curatorial donde la obra de ni un artista «oficialista» fue incluido en la muestra. Tampoco la de otros artistas con un trabajo conceptual relevante en el país ni incluso aquellos que se encontraban en el exilio o viviendo en el extranjero de forma voluntaria.

La operación curatorial y comunicacional deja ausentes a muchos artistas, y en particular algunos que llaman especialmente la atención. Primero que todo, cabe destacar la ausencia de los artistas viviendo en España (y en Europa en general, por cercanía). Si la tematización era la vivencia de Chile en dictadura, y se incluye una obra de Roberto Matta (quien vivió fuera de Chile desde 1933), resulta a lo menos extraño no haber incluido obras de quienes vivían y trabajaban a este lado del Océano9. De los que se encontraban en España, fueron excluidos tanto los artistas exiliados (Dolores Walker, Carlos Vásquez, Patricio Court, Raúl Eberhard, Paca Jilberto, Pablo Siebel) como quienes vinieron a vivir a España por voluntad propia (previa o posteriormente al Golpe de Estado), particularmente los hiperrealistas, corriente pictórica donde el arte chileno ha tenido un fuerte nicho de reconocimiento (Gastón Orellana, Claudio Bravo, Aldo Bahamondes, Guillermo Muñoz Vera).

Del resto de artistas chilenos residiendo en el extranjero ni uno fue incluido. Particularmente en Nueva York se había generado un nicho importante de artistas emergentes vinculados, en su mayoría, a la utilización de nuevos medios y tecnologías: Alfredo Jaar ${ }^{10}$, Catalina Parra, Jorge Tacla, Cecilia Vicuña o Eugenio Téllez, por nombrar algunos, no estuvieron presentes a pesar de que muchos de ellos realizaran una reflexión vinculada a la recurrente tematización del problema de Chile que guiaba la exposición. Juan Domingo Dávila, radicado en Australia desde 1974 y uno de los artistas chilenos con mayor repercusión internacional, tampoco fue invitado a la exposición.

Cabe destacar también la ausencia de la obra de importantes artistas radicados en Chile, como el conceptualismo crítico de Carlos Altamirano ${ }^{11}$ o Arturo Duclos y las acciones del C.A.D.A. (a excepción de un videoarte de Rosenfeld), que fueron anteriormente el envío no-oficial de Chile a la $12^{\text {a }}$ Bienal de París (1982), a través de video-registros y fotografías con Nelly Richard como curadora.

9 Cabe destacar sí la realización del acto «Chile lejos» (de seis horas de duración), en el marco de la exposición, en la sala San Pol el lunes 2 de febrero, donde, según comenta la prensa, cerca de cuarenta artistas chilenos de todas las disciplinas, residentes en Madrid, realizaron variadas "actividades» en el encuentro con aquellos que viajaron desde Santiago. Exposiciones posteriores han «subsanado» esa herida en el arte del exilio o migrante ausente. Algunas de ellas han sido: Artistas Chilenos en España, Casa de América, 1996; Pintura Chilena, Galería Aritza, Bilbao, 1998; Artistas chilenos en San Lorenzo de El Escorial, Museo de América, Madrid, 2002.

10 Jaar, tras dejar Chile en 1982 (y su problematización con intervenciones en el espacio y en la ciudadanía como su obra Estudio sobre la felicidad), realiza un giro geopolítico/etnográfico de su oficina a Nueva York y su obra hacia África. Participa un año antes de esta exposición en la Bienal de Venecia y dos años después en la exposición Magiciens de la terre (París).

11 Altamirano luego participará en la Exposición Universal de Sevilla 92, en la exposición titulada «Artistas latinoamericanos del siglo XX», organizada por el MoMA de Nueva York. 
Los otros estuvieron ausentes de esta historia del arte chileno que aglomera de los años 60 en adelante, que borró pulcramente las discusiones conceptuales y visuales de las distintas escenas presentes y que en Madrid se presentó en formato de edición como un modelo estructurado (de transición) e histórico, realizando una lectura como invención del arte chileno a partir de ciertos códigos de poder de las escenas plásticas nacionales.

\section{EXPOSICIÓN METONÍMICA}

La exposición Chile Vive se muestra como presencia diferida (signo, en términos derridianos) de un naciente Chile Modelo (global) que se despliega en el espacio extranjero sin dar cuenta de la imposibilidad o complejidad de establecer un montaje estético que englobe lo nacional. La exposición nacional se presenta como revisitación y resignificación de la historia para plantear al arte en un espacio político (sin ser necesariamente un arte político-comprometido) cuya imagen solo quiere presentar la diferencia política (y las similitudes: Pinochet/Franco) del Chile del momento, más allá de las problemáticas formales que plantean las propias obras: éstas cumplen una función documental-sociológica de la existencia de actividad en tiempos de dictadura. En este sentido, dos son al menos las pulsiones que mueven la exposición: por un lado, se exhibe de forma «indiscriminada» el quehacer chileno en Dictadura (se exhibe el país en España), como documento histórico más que como problema del arte, y por otro, se re-internacionaliza la producción nacional en términos programáticos más allá de las acciones de otros artistas particulares, en una búsqueda de satisfacer un deseo de identidad nacional y validación internacional.

En este sentido es posible pensar la exposición como un gesto de solidaridad de un país a otro que se ve como hermano, pero también como hijo o como amante. La relación se establece necesariamente incestuosa, en cuanto hermano menor al que se celebran los avances vanguardistas, la fuerza escultórica y la profundidad dramática, hermano menor que en los años 60 y comienzos de los 70 pudo ser mayor (en cuanto a alfabetización y otras variables de acceso a la cultura y la educación) o pudo ser un amante. La recepción se torna ineludiblemente conflictiva, cuestionable en su piedad desinteresada a tan solo cinco años del V Centenario de la conquista de América. Menos casual resulta esto considerando que

tras aquella exposición de 1963 de Arte de América y España, sobrevinieron casi tres décadas en las que el vínculo entre la península y las naciones americanas se cimentó en acciones esporádicas [...]. Tres años antes de la celebración del quinto centenario, en 1989, se organizó otra exposición fundamental, la titulada Art in Latin America [...]. Tras ser presentada en Londres, la muestra fue exhibida en Madrid, con el patrocinio del Ministerio de Cultura y la Comisión del Quinto Centenario, bajo la denominación de Arte en Iberoamérica 1820-1980. España comenzaba a recuperar su sitio como escenario principal del arte latinoamericano, perdido varias décadas atrás (Bellido Gant, 273-4).

Chile Vive fue probablemente en su momento la exposición nacional más grande realizada nunca, tanto dentro como fuera del país, pero en su estructura de discurso alegórico armado para el extranjero - como el de una Exposición Universal (en pequeño y particular) para invadir un centro (el centro de Madrid) - y en una temporalidad tan 
reducida, no transformó la situación referencial/contextual, no dialogó con la escena en la que se insertaba. Más que un inserto, se convirtió en un montaje ordenado y abarcador (fácilmente desmontable) de una escena nacional de por sí fragmentada.

Se intentó realizar una puesta al día de escenas eclécticas, en una clara tensión temporal-generacional que la muestra no explicita: presentación tardía (a des-tiempo) de lo institucionalizado en el arte chileno como problematización de un tema (ilusión de unidad interna), como ficción escenificada sin repercusiones mayores. De ahí también la ficción del título de este ensayo: un texto unitario, que cita el trabajo de Dittborn delachilenapintura, historia, con una estructura distinta a una redacción "correcta» que facilitaría su lectura, dando cuenta de los medios/estrategias/diferencias por los que la escena nacional logró, unificadamente, salir fuera en Dictadura.

Este régimen de coexistencia de la historia del arte chileno, donde se borronean las relaciones de poder en el arte ante el ojo foráneo, genera una coherencia interna superficial que en el espacio madrileño opera de forma ordenada, sistematizada, segmentada racionalmente, dejando encubiertos todos los procesos de fractura plástica y teórica que se encontraban allí. El arte se presenta como una excusa por parte de la política (arteutilidad) en cuanto deja fuera las propias reflexiones que la plástica puede plantear a la política en sus propias condiciones históricas de producción. En lugar de plantear un problema a la política, un cuestionamiento, la exposición en su totalidad es vista como una representación de una contingencia.

Las cartografías comisariales se tornan entonces representativas/cionales de la escena artística chilena de los últimos 30 años como un ejercicio arriesgado y eminentemente imposible de completar: asunto no desdeñable, el de la representatividad, cuando se presentan, por ejemplo, 16 obras de 3 escultores, y 48 «pinturas» de los 14 artistas visuales, considerando la cantidad de excluidos de la exposición. Gesto de control/manejo de la escena artística chilena — no como apertura de nuevos radios de circulación internacional- y de los marcos de operancia de las obras: Chile aparece representado (ilustrado políticamente) como magnitud histórica total, progresiva y moderna, incapaz de presentar fugaz, disensos o distanciamientos. Chile vive en esta lógica representativa no se articula a partir de conceptos artísticos sino que temporales y espaciales, en obras producidas en dictadura de resistencia representativa del arte con la política. Las decisiones comisariales editan con criterios de selección aunados en una idea de resistencia solidaria, lo que si bien podría ser coherente, aúna a esas prácticas por un criterio ajeno a ellas, y a la vez, deja fuera a obras y artistas que desde otras estrategias podrían haber generado una mirada distinta y complejizada a lo presentado, quizá mucho más cercanos incluso a la resistencia en términos artísticos que algunos de los presentes.

Se salió de Chile en busca de una respuesta, un feed-back de la propia identidad (la del hijo con su madre) y la respuesta a aquella pregunta no fue encontrada, no fue apuntalada por la crítica, no se sacó al arte chileno de su familiaridad referencial que ignora por un momento en ese espacio sus problemas históricos de construir una imagen unitaria de país. El sistema reconstructivo que planteó la exposición puso al descubierto finalmente el problema de lo chileno en su exceso expositivo que da cuenta de su negativo, de su imposibilidad de imagen.

El objetivo político-institucional de los organizadores de Chile Vive fue cumplido, en cuanto demostración de vida cultural en Chile a pesar de las censuras de la Dictadura, pero en términos artísticos esto opacó las posibilidades de presentación compleja de las 
escenas presentes. El problema de la muestra no estuvo solo en su selección de artistas, sino que en el foco solidario (de sobre-vivencia) que quitó peso a la construcción de una historia del arte anacrónica (a la vez contemporánea y viva) que diera cuenta de las complejidades estéticas y procedimentales de muchas de las obras, las cuales perpetuaron grados altos de ilegibilidad (lenguaje cifrado y etnocéntrico) en una presentación que no planteaba problemas estéticos sino que particularidades plásticas aisladas que eran subsanadas por el discurso solidario, lo que se tradujo en una desactivación de las estrategias que se re-plantearon la relación arte/política desarrolladas en el espacio local, para activar un discurso unitario-postgolpista.

En esta política solidaria, lo autóctono apareció como búsqueda de la diferencia -que no tuvo un carácter exotizante ni folclorizante (más allá del telar popular presentado en la sección de la Vicaría de la Solidaridad a propósito del Premio Príncipe de Asturias de la Libertad recibido el año anterior) - en imágenes esperadas de una América necesariamente sufriente, pero que a la vez resulta paradójica: por un lado, se adelanta el festejo de la deseada transición a la democracia chilena (imitativa, por cierto, de la española), de reconfiguración nacional a partir de los residuos ya rearticulados que había dejado el quiebre refundacional de la historia por parte del régimen; y por otro, ésta es puesta en estado de diferimiento, realizando una operación de ayuda-memoria con relación a la experiencia del franquismo y sus repercusiones (como respuesta al amor homopaternal de Pinochet por Franco, único «estadista» al cual declaró su admiración).

Se estableció así una relación extraña con España, como madre para Chile (en un bautizo refundacional internacional), como hermano para la prensa española, como cónyuge para otros (en la dicha y la adversidad) y tal vez como rival del nuevo padre de la patria (o las patrias latinoamericanas) en el peso neoyorquino en el arte latinoamericano del siglo XX. La relación, como ya se planteó, fue incestuosa, relación desigual de amantes (filiación nominal: el Guernica surrealista chileno) donde Chile realiza una operación de exhibición(ismo), en búsqueda de una inserción internacional del arte vía solidaridad confesa del gobierno español: Chile Vive significó para la historia y crítica de arte chilena esa inserción, su validación, pero no fue un punto de partida de profundización de relaciones internacionales sino que la confluencia de pensamientos variados y opuestos expuestos pulcramente para luego volver a desvanecerse. La exposición-instrumento solidario español ayudaba a levantar Chile vía un gran discurso voyeur (solidario/documental) de una ilustración circunstancial (imagen «nueva»), sin mayores repercusiones en el sistema del arte internacional (ni español en particular).

\section{CARTOGRAFÍAS PROYECTIVAS}

Como se ha ido esbozando, estas decisiones curatoriales se insertan en un cierto intento/ interés de relación postcolonial, como eterno retorno a una historia de relaciones desiguales, pero no de forma lineal, sino que las nuevas intenciones españolas con Latinoamérica se articulan con la intelectualidad nacional en su afán de internacionalizar el arte chileno (un año antes, Richard había lanzado su libro Márgenes e Instituciones en Melbourne), conjugando un espacio de articulación conceptual como cartografía de relaciones ambiguas que se institucionalizan. La exposición se presenta necesariamente car- 
tográfica, como los planos de la conquista (como posicionamiento internacional / selección representativa), a partir de mapeos disciplinares propios del Círculo de Bellas Artes (categorías propias de la escena del Círculo aplicadas a la escena chilena, sin considerar las relaciones complejas plástica/videoarte y plástica/literatura). El proyecto se presenta entonces - tal cual lo hace un mapa-más informativo (selectivo), inventivo (diagramal) y político (dependencia representativa) que estético (reflexividades visuales) y cultural.

La exposición Chile Vive en Madrid pone en cuestión así el problema de localización del arte, a partir del desplazamiento a un espacio museográfico que des-ubica de su contexto debates propios de la producción plástica chilena a partir de la vitalidad de un proceso político que se estaba acabando. Distinta es la estrategia de la exposición de Berlín que se centra en el despliegue de la «Escena de Avanzada»: Cirugía Plástica (1989) se presenta como una recomposición médico-estética de la muestra de Madrid. En el catálogo de dicha exposición Nelly Richard plantea a Chile Vive como

primera muestra institucional destinada a recrear - a escala internacional- el paisaje artístico del período de la dictadura, antecedente obvio (y contrastante) de la muestra en Berlín, que elige favorecer la representación de la «avanzada», dejando fuera la neopintura crítica del expresionismo-primitivismo de Bororo y Benmayor y la pintura contestataria (Antúnez, Balmes, Barrios, Bru, etc.) que simboliza la expresividad dominante de la izquierda político-cultural chilena («Sobre arte y política(s)», 41).

Valida Richard su concepto frente a la amenaza de la historia y la memoria que representaban los artistas de las estéticas pre-73 y el auge pictórico post-«Avanzada» en la escena del arte nacional. En el caso de otra exposición, el retorno a la pintura (Benmayor, Bororo, etc.), alejado de teóricos que lo validara, fue hegemónico, en virtud de las recuperaciones de la curatoría ejercida por el Stedelijk Museum de Ámsterdam (1990). Continúan así los debates y disputas por la inserción internacional como sitial de poder en el arte.

Todas estas operaciones van a tener repercusiones en un evento mayor a nivel internacional: la Exposición Universal de Sevilla 92, la cual es engalanada con una serie de dinámicas con fuertes tentaciones postcoloniales que acompañan el posicionamiento de España con relación al arte latinoamericano: en su interior se presenta la exposición Arte latinoamericano del siglo XX (curada por el MoMA), Madrid fue ese año Capital Cultural de Europa y se crearon instituciones como el CEXECI (Centro Extremeño de Estudios y Cooperación con Iberoamérica), el MEIAC (Museo Extremeño e Iberoamericano de Arte Contemporáneo) y la Casa de América (Madrid). En este contexto se establece en la Exposición de Sevilla, por parte de Chile, un vínculo transiciológico y de representación del Chile Modelo/Moderno a través del iceberg (prolongación de la exposición como modernidad de Chile en los desarrollos vanguardistas en el arte y su apropiación de estrategias plásticas «internacionales»), como «discurso de cambio» (cambian también los artistas chilenos invitados) para ilustrar una narración pausada del olvido de la memoria, de la pulcritud de la patria, de su frialdad y perfección (casi-natural, como el iceberg), proyectando institucionalmente nuevas hegemonías geopolíticas en los debates curatoriales, que se sitúan en diálogos fronterizos a través de nuevas (blancas y limpias) políticas de visualidad y representación, en nuevos trasvasijes de identidad en la relación entre arte y política. 


\section{REFERENCIAS}

Antúnez, Nemesio. "Chile vive». Chile Vive: memoria activa. Ed. Gutiérrez, Paulina. Santiago: CENECA-Instituto de Cooperación Iberoamericana, 1987. 31-33. Medio impreso.

Bellido Gant, María Luisa. «Derroteros del arte latinoamericano en España». Arte latinoamericano del siglo XX. Otras historias de la Historia. Gutiérrez Viñuales, Rodrigo (director). Zaragoza: Prensas Universitarias de Zaragoza, 2005. 263-284. Medio impreso.

Brunner, José Joaquín. "Cultura y Sociedad en Chile». Chile Vive. Muestra de Arte y Cultura. Madrid: Círculo de Bellas Artes, 1987. 15-21. Medio impreso.

Derrida, Jacques. La diferencia (Différance). Trad. de Aquiles Trujillo. Santiago: Escuela de Filosofía Universidad ARCIS, 1968. Medio impreso.

-. Cómo no hablar y otros textos. Barcelona: Proyecto a Ediciones, 1997. Medio impreso.

Díaz, Gonzalo. "Cómo tirar la casa por la ventana, de la desidia». Chile Vive: memoria activa. Santiago: CENECA-Instituto de Cooperación Iberoamericana, 1987. 34-37. Medio impreso.

Didi-Huberman, George. Devant Le Temps. Histoire de l'art et anachronisme des images. París: Les Éditions de Minuit, 2000. Medio impreso.

García-Garzón, Juan. «Roberto Matta, conjugador del verbo América». ABC Literario (1987, 24 de enero). Medio impreso.

González García, Ángel. «Chile al revés». Cambio 16 (1987, 2 de febrero). Medio impreso.

Ivelic, Milan. «Artes visuales: una mirada crítica». Chile Vive. Muestra de Arte y Cultura. Madrid: Círculo de Bellas Artes, 1987. 52-65. Medio impreso.

Mosquera, Gerardo. «El mundo de la diferencia. Notas sobre arte, globalización y periferia». El Síndrome de Marco Polo, Problemas de la comunicación intercultural en la teoría del arte y la práctica curatorial. Berlín: Simposio Internacional, Haus der Kulturen der Welt, 1995. Sitio Web. Fecha de ingreso: 10 de julio de 2008.

Oliva, María Victoria. «Arte y cultura de un pueblo que no se doblega». El Público (1987, febrero). Medio impreso.

Pérez, David. «Pluralismo e identidad: el arte y sus fronteras». Horizontes del arte latinoamericano. Jiménez, José y Fernando Castro (eds.). Madrid: Tecnos, 1999. 15-24. Medio impreso.

Richard, Nelly. Margins and Institutions. Art in Chile since 1973. Melbourne: Art\&Text Editors, 1986. Medio impreso.

- La estratificación de los márgenes. Sobre arte, cultura y políticas. Santiago: Francisco Zegers Editor, 1989. Medio impreso.

—. «Sobre arte y política(s): contraoficialidad, poder y lenguaje». Cirugía Plás-tica: Konzepte Zeitgenössischer Kunst Chile 1980-1989. Berlín: Neue Gesellschaft für Bildende Kunst, 1989. Medio impreso.

-. «El régimen crítico-estético del arte en el contexto de la diversidad cultural y sus políticas de identidad». Real/Virtual en la estética y la teoría de las artes. Marchán Fiz, Simón (comp.). Barcelona: Paidós, 2006. Medio impreso. 
Rojas, Sergio. «La visualidad de lo fatal: historia e imagen». Pensar en/la postdictadura. Richard, Nelly y Alberto Moreira. Santiago: Editorial Cuarto Propio, 2001. 285-297. Medio impreso.

Recepción: 21 de mayo de 2010

Aceptación: 18 de junio de 2010

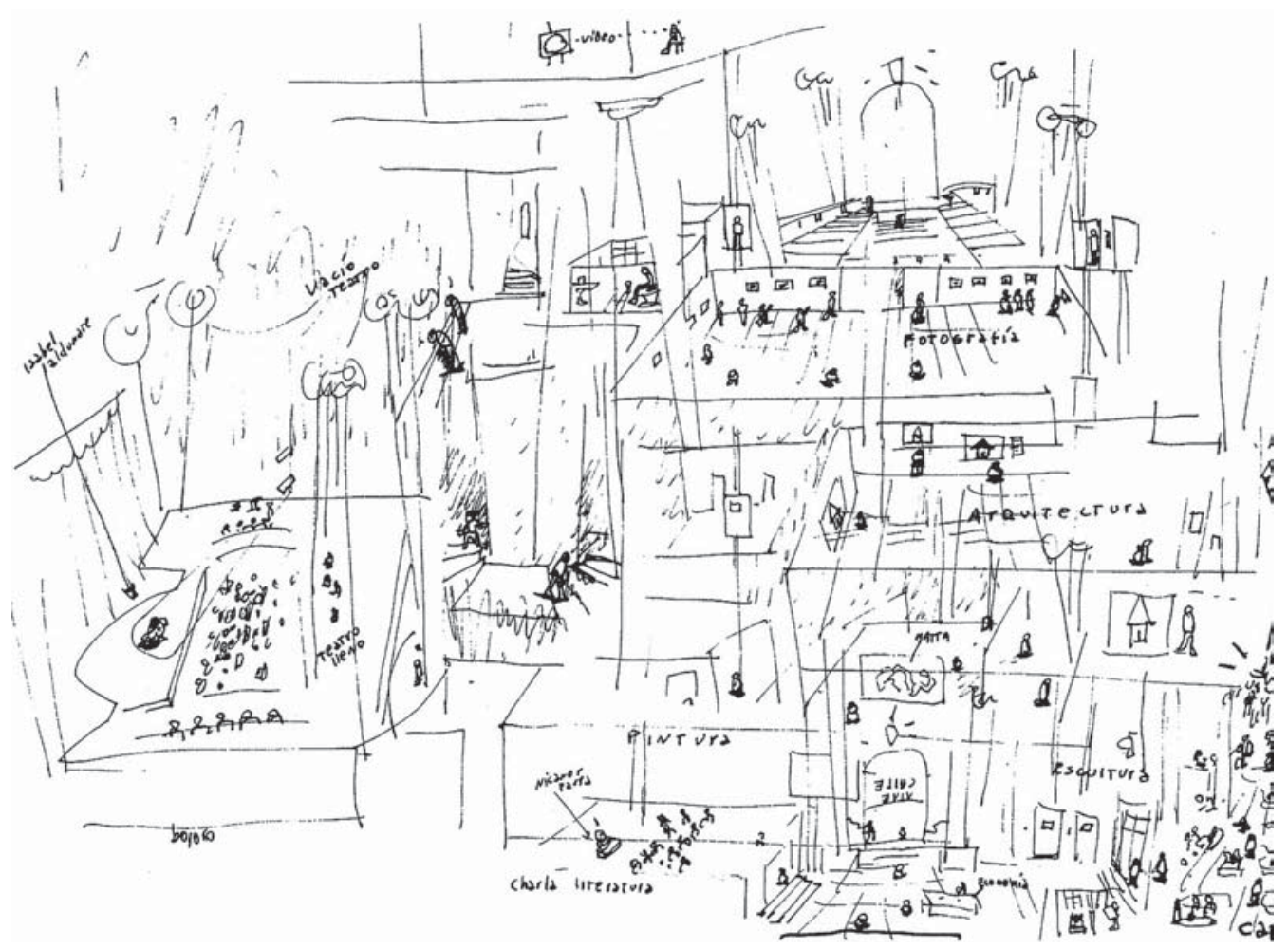

Fig. 1: Benmayor, Samy (1987), dibujo de de la distribución de salas de Círculo de Bellas Artes de Madrid para Chile Vive. (c) Chile Vive: memoria activa. 


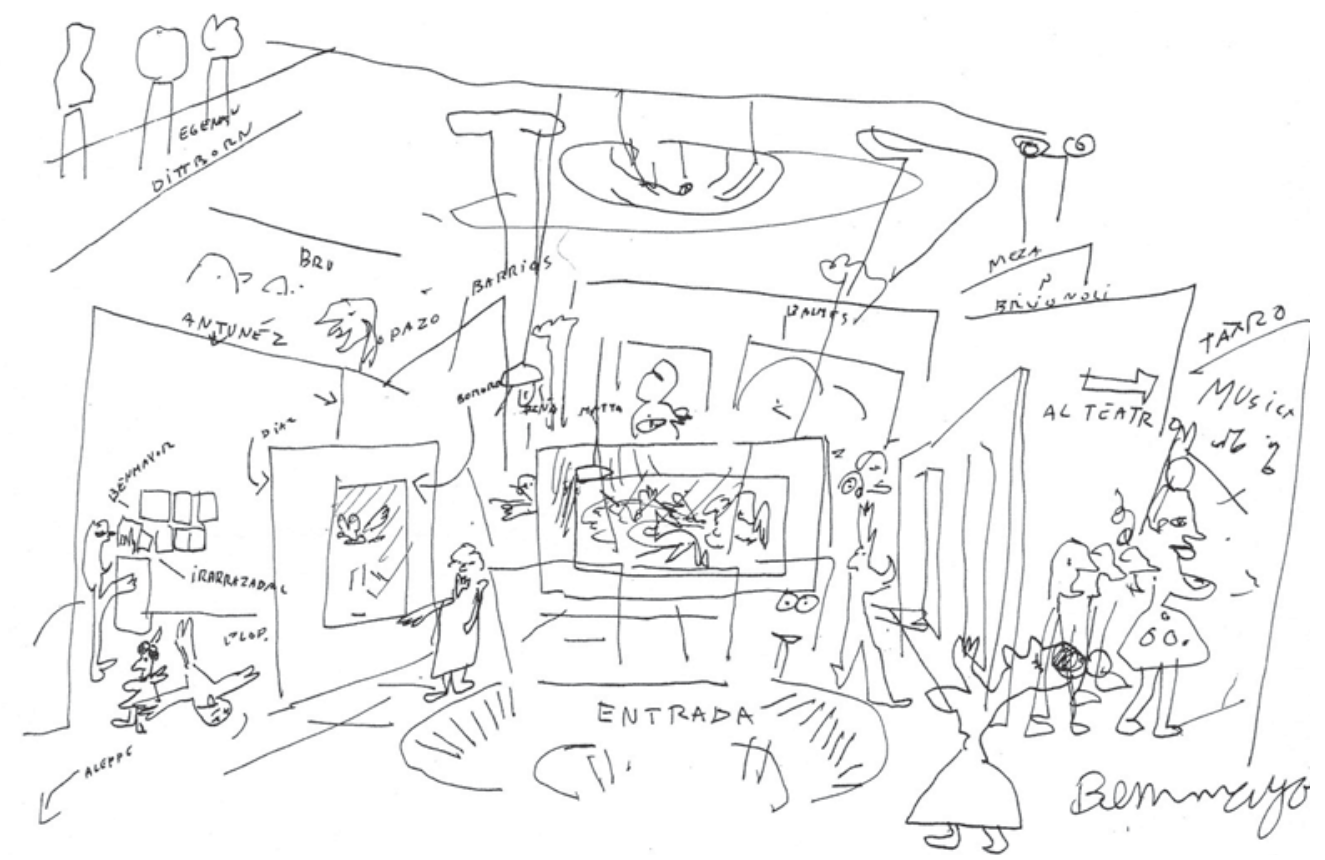

Fig. 2: Benmayor, Samy (1987), dibujo de de la distribución de la sala de artes plásticas de Chile Vive. ๑ Chile Vive: memoria activa.

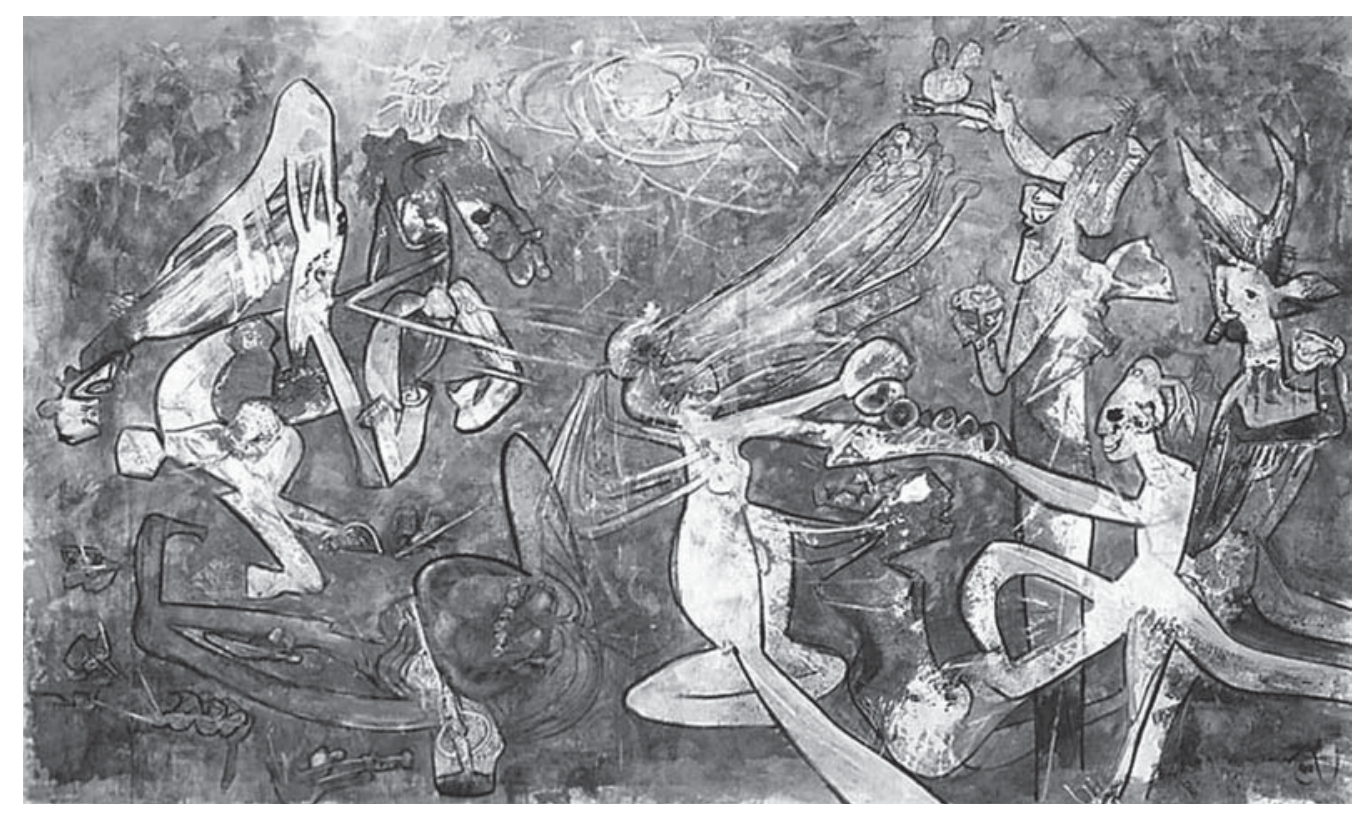

Fig. 3: Matta, Roberto (1986), Munda y Desnuda: la libertad contra la opresión, óleo sobre lienzo, 2,5 por 4 metros. ( Museo Nacional Centro de Arte Reina Sofía. 


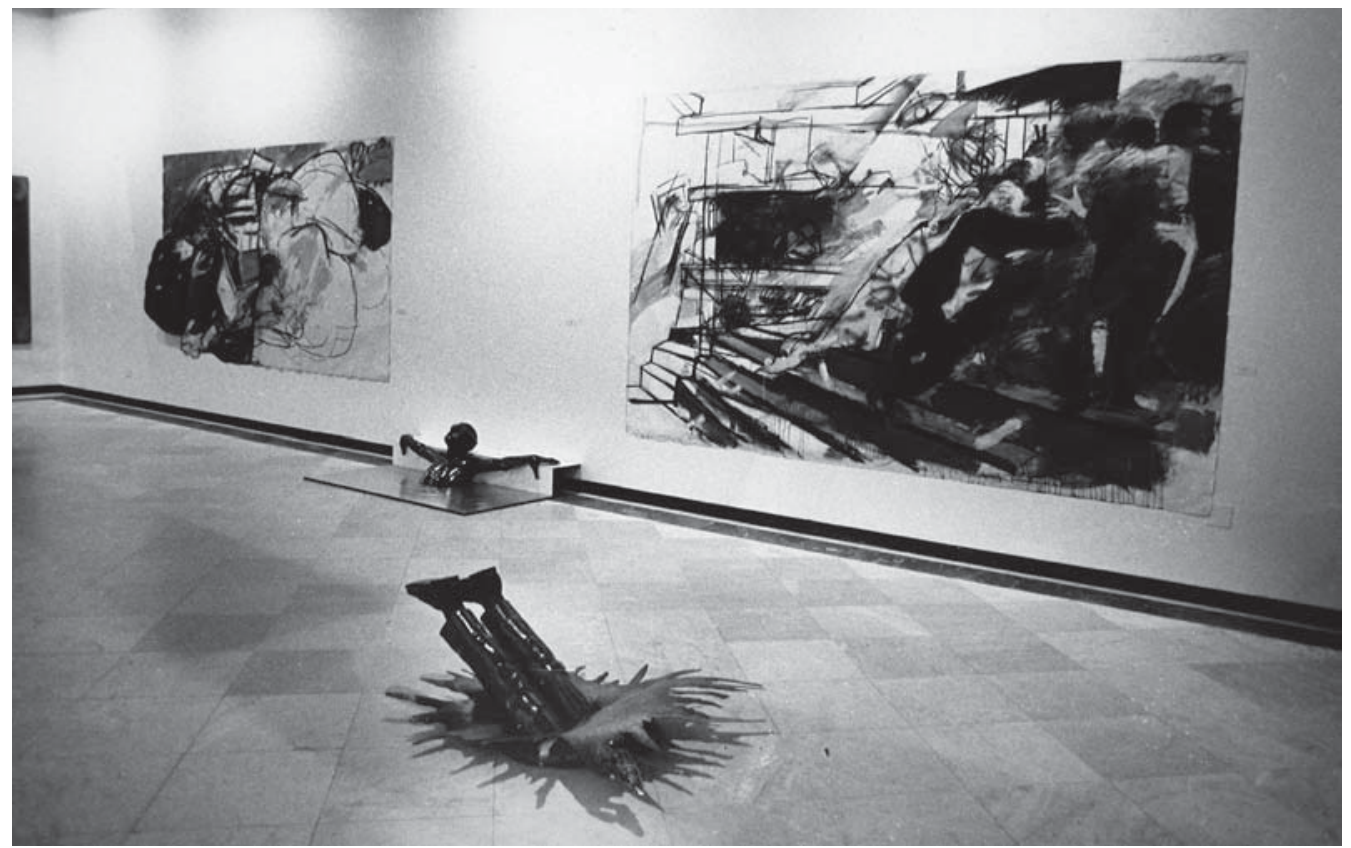

Fig. 4: fotografía de pinturas de José Balmes y esculturas de Juan Egenau en Chile Vive. @ Enrique Castellano.

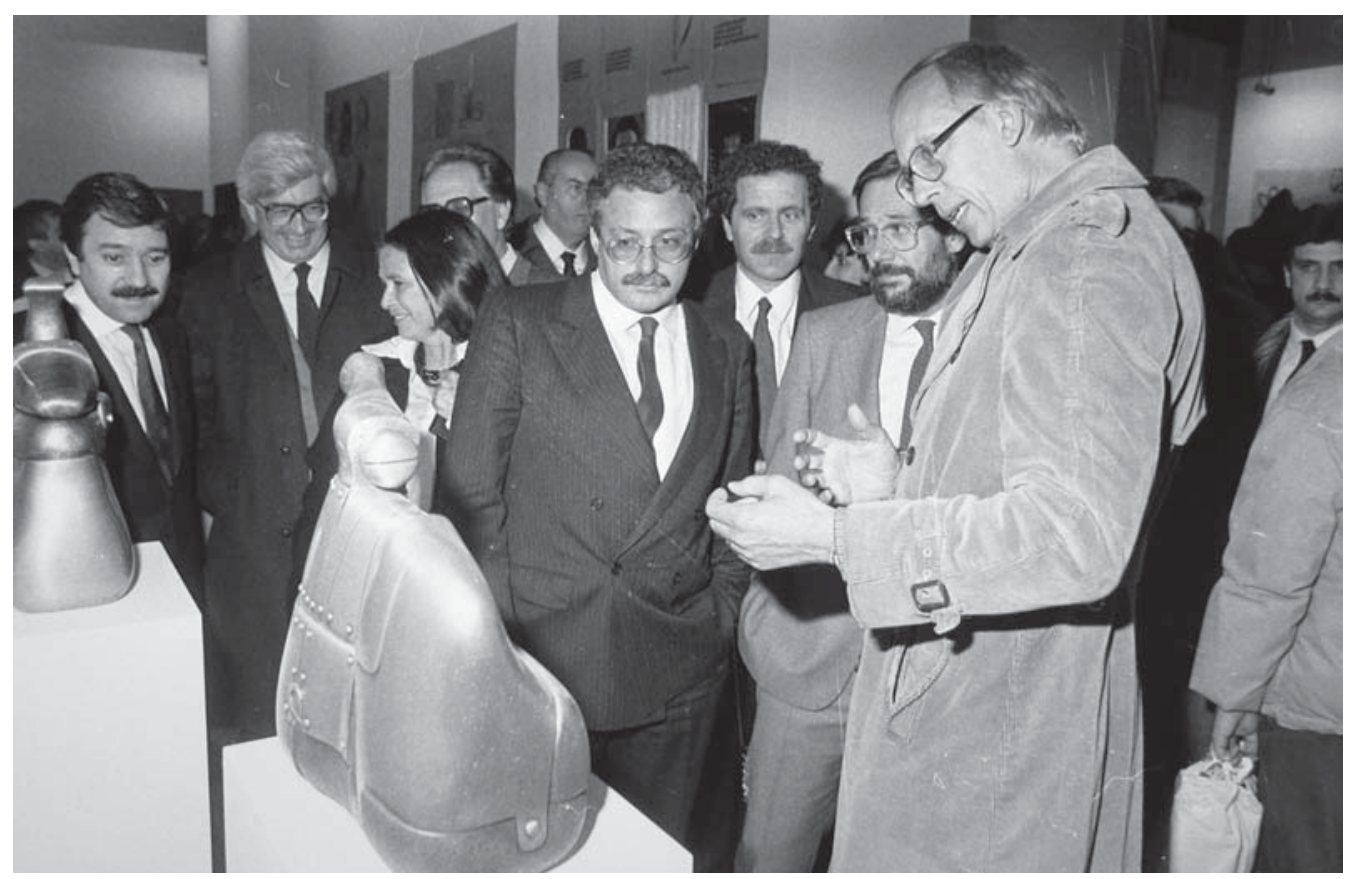

Fig. 5: fotografía de Milan Ivelic explicando las esculturas de Juan Egenau a Joaquín Leguina (Presidente de la Comunidad de Madrid), Javier Solana (Ministro de Cultura), Manuel Borja-Villel (actual Director del Museo Nacional Centro de Arte Reina Sofía) y otros en la inauguración de Chile Vive. @ Enrique Castellano. 


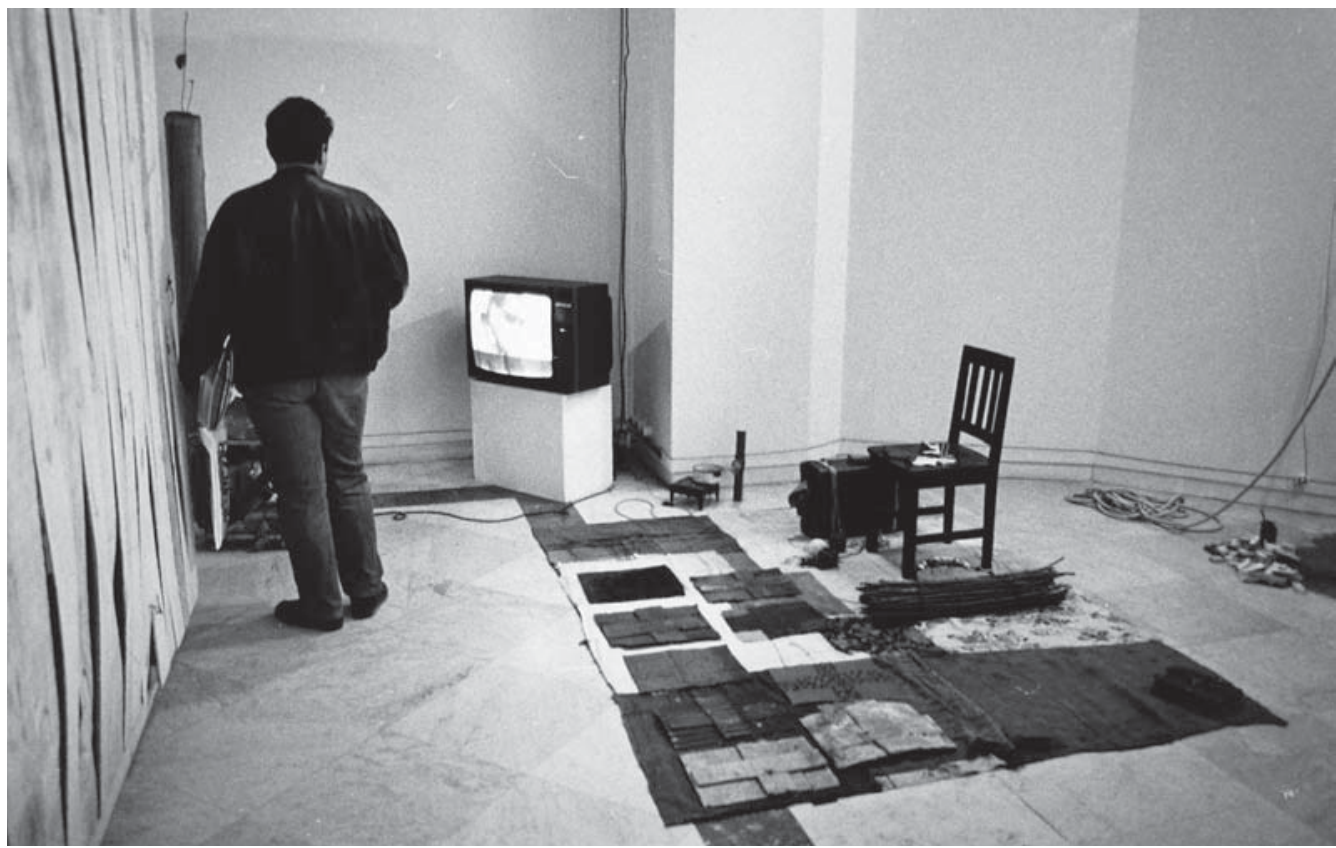

Fig. 6: fotografía de un fragmento de la instalación self-portrait de Carlos Leppe (1987) en Chile Vive. @ Enrique Castellano.

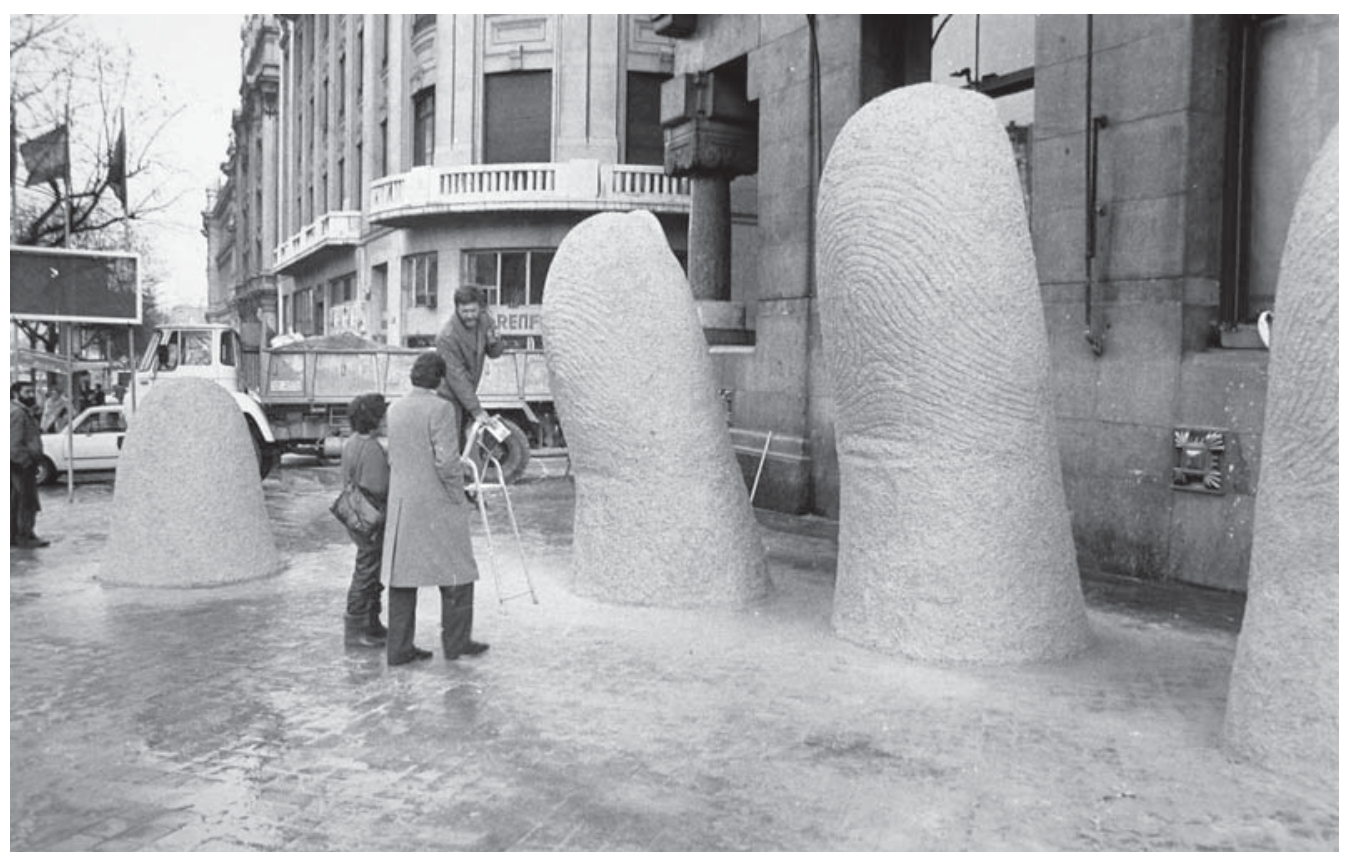

Fig. 7: fotografía de Mario Irarrázabal instalando su escultura Mano en la acera de la calle de Alcalá, frontis del Círculo de Bellas Artes de Madrid. @ Enrique Castellano. 
204

AISTHESIS No 48 (2010): 186-204

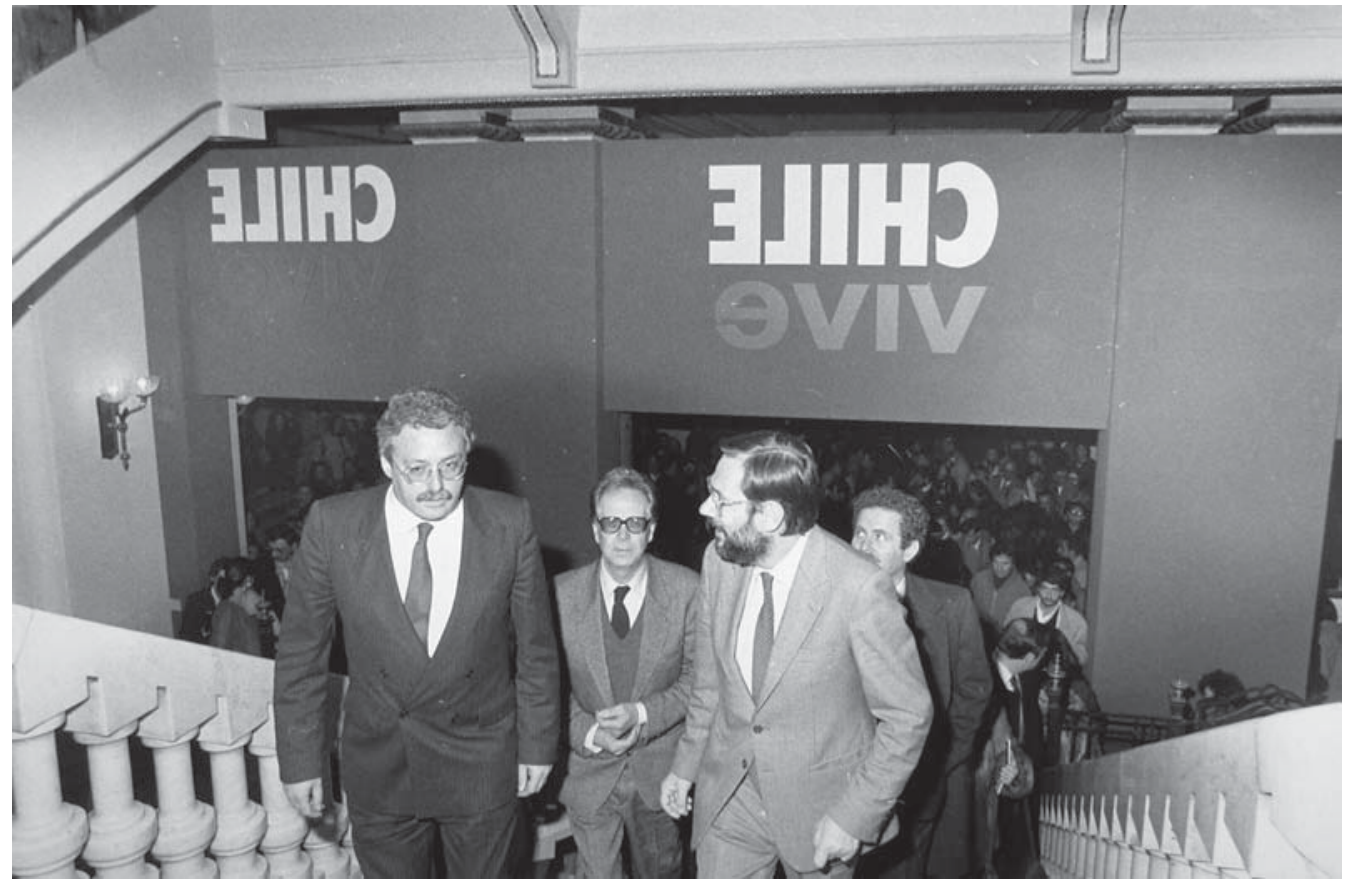

Fig. 8: fotografía de la escalera de acceso a la primera planta del Círculo de Bellas Artes el día de la inauguración de Chile Vive. En primera fila, Joaquín Leguina y Javier Solana. @ Enrique Castellano. 